\title{
Implementing Integrated Multicultural Instructional Design In Management Education
}

Jennifer L. Schultz, Metropolitan State University (MN), USA Jeanne L. Higbee, University of Minnesota, Twin Cities, USA

\begin{abstract}
This purpose of this paper is to summarize the principles of integrated multicultural instructional design (IMID; Higbee, Goff, \& Schultz, in press; Higbee, Schultz, \& Goff, 2010) and present specific strategies for incorporating IMID in management education. The primary goal of IMID is to promote the integration of multicultural content and diverse teaching and learning strategies in postsecondary curricula, programs, courses, and academic support services. Results of a pilot project will be presented that include student evaluations of faculty teaching methods; inclusion of multicultural course content; strategies for the assessment of learning; and commitment to diversity, multiculturalism, and social justice when IMID is embedded in the curriculum. This paper also includes a discussion of andragogy related to multicultural strategies and the creation of inclusive learning environments in collegiate management education.
\end{abstract}

Keywords: Management Education; Integrated Multicultural Instructional Design; Student Diversity

\section{INTRODUCTION}

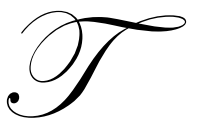

he pervasiveness of diversity issues within organizations cannot be ignored, nor can the importance of a comprehensive understanding by employees of ways to best address diversity. Sadly, many management education programs have not been proactive in the inclusion of diversity interventions in the curriculum and research agendas of business faculty rarely include issues of multiculturalism. Many business schools have ignored diversity-related topics from their curriculum. The purpose of this paper is to present a possible integrated multicultural approach for management education academic programs. The paper presents an overview of the integrated multicultural instructional design (IMID) framework, followed by results of a pilot project that incorporated IMID into a management education classroom. Ending with a presentation of practices, this paper is intended to provide a starting point for dialogue on embedding multicultural principles across the curriculum.

\section{BUSINESS CASE FOR DIVERSITY}

Current and anticipated labor forces and markets are becoming increasingly diverse by gender, race, ethnicity, and nationality. Two decades ago, Johnston (1991) elucidated the urgency and critical nature of this demographic shift because global industrial leaders simply did not have enough talent to replace aging workforces. This continuing shortage will inevitably stymie growth throughout the world. Firms will undoubtedly have to rely on immigration, migration, and workers from populations currently underrepresented in the labor force. The four trends of special interest to management practitioners and scholars in this shift are: (a) global alliances; (b) globalization of labor force, markets, products and services; (c) network structures; and (d) diversity in labor and consumer markets (Johnston, 1991).

Wilson (2006) noted that work environments that are perceived as diverse have higher employee engagement, satisfaction, loyalty, and retention. Employees in these environments also tend to be more productive, 
profitable, safer, and have stronger customer relationships, in contrast to less engaged employees who cost companies in productivity losses, worker's compensation claims, and wasted time (Wilson, 2006). In addition to higher levels of employee engagement, research has established a link between successful diversity interventions and corporate profitability, as well as negative impacts of unsuccessful initiatives. Success metrics include diverse leadership, the ability to be more innovative, higher morale, ability to attract better talent, increased access to new markets, better business partners, and the capacity to merge more easily with other organizations (Kuczynski, 1999).

Cox and Blake (1991) identified the organization benefits for managing cultural diversity in terms of competitive advantage through the relationship to cost, resource acquisition, marketing, creativity, problem solving, and system flexibility. Jackson, Joshi, and Erhardt (2003) concluded that only through active diversity management will organizations be able to fully realize the potential of their diverse workforces, yet noted the shortcomings in understanding how to create diversity-related change. The issue of diversity is complex, and precariously balances individual, social, familial, and other personal and societal issues that are difficult if not impossible to alter.

Diversity, by definition, recognizes differences in social identities. However, it is not limited to the social constructs of race and ethnicity alone. Loden (1996) included race and ethnicity as primary diversity dimensions along with age, gender, mental-physical abilities and characteristics, and sexual orientation. These are categorized as core dimensions to understanding diversity due to their influence on early socialization and development, as well as their impact over the lifespan. Significant secondary dimensions include communication style, education, family status, first language, geographic location, income, military experience, organizational role and level, work experience, and work style. These aspects are viewed as less important dimensions because they are not always visible, nor are they results of pure socially-constructed dynamics (Loden, 1996).

\section{INTEGRATED MULTICULTURAL INSTRUCTIONAL DESIGN MODEL}

IMID is a third-generation model that builds on previous models and research related to multiculturalism (Bruch, Higbee, Jehangir, \& Siaka, 2004; Bruch, Higbee, \& Siaka, 2007; Bruch, Jehangir, Lundell, Higbee, \& Miksch, 2005; Ghere, Kampsen, Duranczyk, \& Christensen, 2007; Higbee, Bruch, \& Siaka, 2008; Higbee, Miksch, Jehangir, Lundell, Bruch, \& Jiang, 2004; Higbee \& Siaka, 2005; Higbee, Siaka, \& Bruch, 2007a, 2007b; Miksch et al., 2003). Previous research found that educators still require diversity-related professional development opportunities despite personal commitments to multicultural education; moreover students also thought that wellintentioned faculty still needed more education in responding to cultural differences (Higbee, Schultz, \& Goff, 2010; Higbee, Siaka, \& Bruch, 2007a). IMID provides faculty with tools to better meet today's postsecondary multicultural pedagogical needs.

The primary goal of IMID is to promote the integration of multicultural content and diverse teaching and learning strategies in postsecondary curricula, programs, courses, and academic support services. The threedimensional representation of IMID is in the form of a pyramid. At its foundation is a collaborative community of postsecondary administrators, faculty, staff, and students who demonstrate their commitment to diversity and multiculturalism through their actions as well as their words and work to ensure that all students feel welcome and supported. From the perspectives of first the learner and then the educator, the four sides of the IMID pyramid represent (a) "how we learn / how we teach", (b) "what we learn / what we teach", (c) "how we access academic support services / how we support learning", and (d) "how we demonstrate what we have learned / how we assess learning." At its apex the four sides of the IMID pyramid come together to achieve self-actualization (Maslow, 1968) for all members of the educational community. The following paragraphs present guiding principles for each of the four sides of the pyramid. It is understood that each side impacts the others.

IMID guiding principles related to how we teach include:

1. Promote understanding of how knowledge and personal experiences are shaped by the contexts (e.g., cultural, social, political, economic, historical) in which we live and work.

2. Work collaboratively to construct knowledge.

3. Understand that learning is a complex process that involves many layers of reflection. 
4. Identify what skills must be developed in order to achieve mastery without excluding students on the basis of nonessential skills.

5. Integrate skill development (e.g., critical thinking, problem solving, written and oral communication) with the acquisition of content knowledge (Higbee, Lundell, \& Arendale, 2005).

6. Establish and communicate clear expectations in terms of (a) learning objectives, (b) engagement in the teaching and learning process, and (c) evaluation measures for teaching and learning.

7. Use teaching methods that consider diverse learning styles, abilities, ways of knowing, and previous experience and background knowledge.

IMID guidelines for content-what we teach—include:

1. Determine what content mastery is essential for each class and for the program or curriculum as a whole.

2. Establish course objectives that reflect essential course components and do not exclude students on the basis of gaps in prior knowledge.

3. Meet or exceed professional standards for excellence in content mastery within an environment of inclusion.

4. Integrate multicultural perspectives within course content.

5. Relate content to historical trends, current events, and future directions.

6. Consider global perspectives.

IMID guidelines for academic support can refer to specific course-related supports as well as various institutional student support services (e.g., learning centers, tutoring programs) and include:

1. Maintain the delicate balance between challenge and support (Sanford, 1967).

2. Support growth in skill development as well as content knowledge acquisition.

3. Address both cognitive and affective aspects of learning.

IMID guiding principles for assessment— the fourth side of the pyramid—include:

1. Develop multiple ways for students to demonstrate knowledge.

2. Encourage students to use creative and critical thinking and problem-solving skills in the process of demonstrating knowledge.

3. Establish a clear link between course or program objectives and the content knowledge and skill acquisition being assessed.

4. $\quad$ Ensure the absence of bias in the assessment of student learning.

5. Use both formative and summative assessment measures.

6. Impose time limits only when relevant to the task or needed as scaffolding for future assessments (e.g., providing timed tests in an accounting course as preparation for the Certified Public Accountant [CPA] examination).

The following paragraphs discuss implementation of these guiding principles in a human resource development course.

\section{PILOT IMPLEMENTATION IN A HUMAN RESOURCE DEVELOPMENT COURSE}

This pilot implementation was part of the "Promoting Inclusion and Retention through Integrated Multicultural Instructional Design (PIRIMID)" project sponsored by the Office for Equity and Diversity at a large public institution in the Midwest. The project spanned the 2008-2009 academic year. The course used as a case study for the purpose of this paper was HRD 5627: Management and Supervisory Development, which is described in the academic catalogue as "Problems, practices, programs, and methodologies relating to the training and development of managers and supervisors, including needed competencies, needs assessment, delivery modes, and evaluation." The course objectives were as follow:

- Students will have clear, concise understandings of human relations and organizational behavior concepts. 
- $\quad$ Students will be able to apply human relations and organization behavior concepts for critical thinking in the workplace, using work applications, case studies, and managerial scenarios.

- $\quad$ Students will develop human relations and organization behavior skills through self-assessment, group skill building, role-plays, and behavior modeling.

The course was an elective graduation requirement for students majoring in Business and Marketing Education (BME) and Human Resource Development (HRD).

\section{How We Teach}

A variety of teaching techniques and methods were piloted that focused on the IMID principles. Personal experiences were brought into the classroom through use of student profile sheets and a "Life Course". The Life Course assignment required students to visually represent their personal, educational, and work experiences over time and then share in pairs or triads with classmates, information that was relevant to their development as a manager. The objectives of this exercise included self-awareness regarding their personal development and disposition for management, as well as a mechanism to engage peers in this reflection of experiences. To support collaborative learning, students were required to use name tents, so that the instructor and classmates could quickly learn all names. By the end of the first night of class, the instructor could identify each of the students by name and knew some specific information about their work and academic experiences. The instructor self-disclosed work and academic experiences to model sharing that supported the scaffolding of personal experiences in learning. All of these initiatives were aimed at helping students feel welcomed and supported.

Higher level cognitive skills were developed in small groups through a variety of case studies in management development; these required students to develop deep, rich, creative thinking that demonstrated systems thinking. The midterm and final exams also included case scenarios and the application of course materials to personal experiences. For example, students were asked to explain a time when their personality traits worked to their advantage and disadvantage at work or school. To demonstrate a responsiveness to students, the instructor completed a midterm evaluation and as a result of student comments made changes to the course. Changes included adding an extra credit assignment, providing additional quiz time through the online class site, reducing the number of essay questions on quizzes, eliminating true-false quiz questions (these were too confusing for were English language learners), and stronger management of classroom discussion.

\section{What We Teach}

This course easily incorporated course content around current events, globalization issues, and "real world" management experiences. The instructor deliberately identified current "hot topics" for discussion in small groups and as part of content delivery. Social identity was an ever present class discussion topic. The class also explored issues of gender, race, and cross-cultural dynamics that impact the workplace. The diversity in backgrounds of students in the class regularly brought international issues into discussions. The instructor worked to encourage and support unique perspectives, making sure that students were heard and respected.

\section{How We Support Learning}

Sanford (1967) suggested that faculty should actively strive for a balance between challenge and support. Learning was supported in the classroom with several organizational mechanisms. At the beginning of class, students were provided with an agenda that recapped the prior class, detailed the content and activities for the current class and provided a forecast of expectations and assignments to be covered during the upcoming week. This communication both established expectations and allowed students to plan and situate their learning amidst other life demands. Learning was also supported with the course website that held the student materials for each class, including handouts, agendas, announcements, and quiz details. Lastly, as mentioned above, student input was solicited via a midterm evaluation where the results were then used to adjust teaching and further support student learning. 


\section{How We Assess Learning}

The evaluation of student learning in this course strategically included multiple assessments throughout the term that catered to a variety of learners. Final grades were a compilation of 12 weekly in-class assignments, three exams, a movie reflection, an executive interview assignment, and an extra-credit activity. No assignment was worth more than $20 \%$ of a student's overall grade. The assignments had variety and deliberately did not include class participation. When the instructor graded student work, names were masked to provide unbiased feedback.

In this class, the quiz format was unknowingly created with an inequitable challenge among students. The course included three online quizzes with multiple choice, true-false, short answer, and essay questions. The midterm evaluation revealed that the nuance in language required to correctly answer a true-false question was a test of translation skills, not content. On essay questions, students who functioned primarily in a language other than English found the time limits too confining and the substantial number of essay items overwhelming. Students would translate the question into their first language, respond, and then translate back to English. The exams were more a test of endurance than course material. The second and third exams were adjusted to focus on questions and format that were content related. Students appreciated the instructor responsiveness and that changes were a clear sign of respect for diversity.

\section{METHOD}

The sample for this pilot project was a cross-listed graduate and undergraduate course at an urban Midwestern public university during spring 2009. The course titled HRD 5627: Management and Supervisory Development met one evening per week and enrolled 32 students-10 (31\%) graduate students (9 masters and 1 doctoral student) and $22(69 \%)$ undergraduate students. Of the 32 students in the class, 7 (22\%) were not born in the United States. The countries represented in the class demographics included Vietnam, India, South Korea, and the Caribbean. There were also several U.S.-born students of color and an even mix of traditional- and nontraditionalaged learners.

Students were recruited in class for participation in this study. The faculty member provided informed consent information verbally and in writing to all students. Participation in the study was voluntary and student responses were anonymous. Student responses to the project course evaluation were entered into an Excel spreadsheet and descriptive data was produced for the PIRIMID pilot project overall (Table 1) and the business case (Table 2) discussed in this manuscript. Students' open-ended short answers were read and reread to gain a deep and rich understanding of the student perceptions related to methods, content, learning, and diversity.

\section{RESULTS}

Of the 32 students enrolled in the class, 30 consented to participate and completed project evaluations (see Appendix). The management case pilot was part of a larger implementation project that involved six faculty members from six different academic disciplines with a total of 116 students participating in the evaluation of the project. Table 1 presents evaluation data for all instructors who completed PIRIMID implementation plans in spring 2009, including the faculty member who taught HRD 5627.

Table 1: Cumulative PIRIMID Course Evaluation Results Spring 2009

\begin{tabular}{lcccc}
\hline $\begin{array}{l}\text { PIRIMID Project Responses for Faculty } \\
\text { Submitting Implementation Plans }\end{array}$ & $\begin{array}{c}\text { Teaching } \\
\text { Methods }\end{array}$ & $\begin{array}{c}\text { Course } \\
\text { Content }\end{array}$ & $\begin{array}{c}\text { Student } \\
\text { Learning }\end{array}$ & $\begin{array}{c}\text { Commitment to } \\
\text { Diversity }\end{array}$ \\
\hline Mean & 9.14 & 9.12 & 9.36 & 9.27 \\
Mode & 10.00 & 10.00 & 10.00 & 10.00 \\
Median & 9.00 & 10.00 & 10.00 & 10.00 \\
Standard Deviation & 1.07 & 1.27 & 0.90 & 1.20 \\
Range (Minimum) & 5.00 & 5.00 & 7.00 & 3.00 \\
Range (Maximum) & 10.00 & 10.00 & 10.00 & 10.00 \\
Number of Responses & 116 & 116 & 113 & 113 \\
\hline
\end{tabular}


Table 2 presents evaluation data for the instructor who taught HRD 5627.

Table 2: HRD 5627: Management and Supervisory Development PIRIMID Course Evaluation Results Spring 2009

\begin{tabular}{lcccc}
\hline & $\begin{array}{c}\text { Teaching } \\
\text { Methods }\end{array}$ & $\begin{array}{c}\text { Course } \\
\text { Content }\end{array}$ & $\begin{array}{c}\text { Student } \\
\text { Learning }\end{array}$ & $\begin{array}{c}\text { Commitment to } \\
\text { Diversity }\end{array}$ \\
\hline Mean & 9.07 & 8.80 & 9.34 & 8.97 \\
Mode & 10.00 & 10.00 & 10.00 & 10.00 \\
Median & 9.00 & 10.00 & 10.00 & 10.00 \\
Standard Deviation & 1.17 & 1.69 & 1.04 & 1.76 \\
Range (Minimum) & 5.00 & 5.00 & 7.00 & 3.00 \\
Range (Maximum) & 10.00 & 10.00 & 10.00 & 10.00 \\
Number of Responses & 30 & 30 & 29 & 29 \\
\hline
\end{tabular}

\section{Student Comments About Teaching Methods}

Students were asked to comment on teaching methods. The majority of comments centered on the assortment of techniques used by the instructor. Most of the comments regarding teaching methods focused on the variety of methods used, for example:

- " "Very thoughtful in including all."

- $\quad$ "She would switch up lesson plans every week to accommodate every kind of learning."

- "Yes, she has done a good job in using different teaching techniques."

- "It's great to learn from different styles."

- $\quad$ "Used a good variety of teaching styles to fit everyone's learning styles and made sure to use multiple styles ... to be able to accommodate all styles."

- "Good variety."

- $\quad$ "Did a great job getting students to engage in class discussion."

- " "I love how she uses different styles, and means of conveying info. Makes class fun and informational."

Overall the variety of approaches was interpreted by students as fun, interactive, and good teaching, this paradigm shift from teaching to learning (Barr \& Tagg, 1995) should be noted by management faculty as a clear directive to move away from the read, lecture, test, and write a research paper course plans that are historically the backbone of business school education. In short, students responded favorably to interactive class sessions that require them to work with other students and develop shared knowledge.

\section{Student Comments About Course Content}

HRD 5627 is a course about management and supervisory development, in which an implicit connection to multiculturalism in course content had previously been a stretch and a nondirect relationship at best. One student expressed appreciation for the pragmatic nature of the course material and relevance to his or her own learning, noting that the course "covers content but doesn't make it boring \& applies it to every-day life." For business faculty, making sure that course material is relevant to the student experience supports student learning on many levels. In developing courses, faculty should pay close attention to incorporating current events, relevant case studies, and projects that connect student work to the course outcomes and resonates in a pragmatic way with the lived experience of the student.

\section{Student Comments On Evaluation Of Student Learning}

Faculty assessment of student performance and attainment of predetermined outcomes can prove to be problematic when multiple methods are used. Student comments noted the numerous and varied opportunities to demonstrate content mastery: 
- " "used a variety of methods to test knowledge \& took feedback into consideration"

- "used various discussion and testing and the assignments to create a good learning environment"

- "very fair - gave students benefit of doubt \& many opportunities"

Several students commented on the constructive and helpful nature of the feedback provided by the instructor. Another student noted, "[she] did a great job getting us to succeed and respecting all of us."

\section{Student Comments Regarding Commitment to Diversity and Multiculturalism}

Lastly, comments were solicited regarding the faculty member's commitment to diversity and multiculturalism and the demonstration of that commitment in teaching methods, course content, and student evaluation schemes. Specifically, one student noted the availability to the instructor, "Good instructor. Made learning fun for everyone. Always made herself available to students." Another commented about the classroom culture, "She is a great teacher-I love her style and she gets everyone involved in her classroom." There was also a student comment specific to the classroom discussion, "There was much discussion about diversity and multiculturalism."

\section{CONCLUSION}

It is clear that all learners benefit in some way when faculty integrate diversity and multiculturalism into the classroom culture. Assignment variety, multiple assessment modes, and increased interaction among students is simply good practice in the management classroom, but it also supports the unique identities and learning needs of our increasingly diverse student populations. Overall, students respond well to faculty who use these techniques, and this should begin the dialog in course redevelopment among business faculty.

\section{AUTHOR INFORMATION}

Jennifer L. Schultz, Ph.D., is an Assistant Professor in Human Resource Management (HRM) for The College of Management at Metropolitan State University in Minneapolis, Minnesota. She serves as the Curriculum Coordinator for the undergraduate HRM program and teaches graduate and undergraduate courses in management and HRM. E-mail: Jennifer.Schultz@metrostate.edu

Jeanne L. Higbee, Ph.D., has worked in higher education since 1974, first in student affairs, and since 1985 in faculty positions. She currently serves as Professor and Director of Graduate Studies for the Department of Postsecondary Teaching and Learning in the College of Education and Human Development at the University of Minnesota, Twin Cities. E-mail: higbe002@umn.edu

\section{REFERENCES}

1. Barr, R. B., \& Tagg, J. (1995). From teaching to learning-A new paradigm for undergraduate education. Change, Retrieved from http://ilte.ius.edu/pdf/BarrTagg.pdf

2. Bruch, P. L., Higbee, J. L., Jehangir, R., \& Siaka, K. (2004). Changing the talk we walk: The multicultural awareness project for institutional transformation (MAP IT). Proceedings of Keeping Our Faculties III Conference: Recruiting, retaining, and advancing faculty of color. Minneapolis, MN: University of Minnesota.

3. Bruch, P. L., Higbee, J. L., \& Siaka, K. (2007). Multiculturalism, Incorporated: Student perspectives. Innovative Higher Education, 32, 139-152.

4. Bruch, P. L., Jehangir, R. R., Lundell, D. B., Higbee, J. L., \& Miksch, K. L. (2005). Communicating across differences: Toward a multicultural approach to institutional transformation. Innovative Higher Education, 29, 195-208.

5. Cox, T. H., Jr., \& Blake, S. (1991). Managing cultural diversity: Implications for organizational competitiveness. Academy of Management Executives, 5(3), 45-56. 
6. Ghere, D. L., Kampsen, A., Duranczyk, I., \& Christensen, L. L. (2007). Adopting and integrating multiculturalism: A closing assessment of General College. In J. L. Higbee, D. B. Lundell, \& I. M. Duranczyk (Eds.), Diversity and the postsecondary experience (pp. 25-36). Minneapolis, MN: University of Minnesota, Center for Research on Developmental Education and Urban Literacy. Retrieved from http://cehd.umn.edu/CRDEUL/docs/monograph/Diversity.pdf

7. Higbee, J. L., Bruch, P. L., \& Siaka, K. (2008). Disability and diversity: Results from the multicultural awareness project for institutional transformation. In J. L. Higbee \& E. Goff (Eds.), Pedagogy and student services for institutional transformation: Implementing universal design in higher education (pp. 405-417). Minneapolis, MN: University of Minnesota, Center for Research on Developmental Education and Urban Literacy. Retrieved from http://cehd.umn.edu/passit/docs/PASS-IT-Book.pdf

8. Higbee, J. L., \& Goff, E., \& Schultz, J. L. (in press). Implementing integrated multicultural instructional design in a first-year seminar. Journal of College Student Retention.

9. Higbee, J. L., Miksch, K. L., Jehangir, R. R., Lundell, D. B., Bruch, P. L., \& Jiang, F. (2004). Assessing our commitment to providing a multicultural learning experience. Journal of College Reading and Learning, 34(2), 61-74.

10. Higbee, J. L., Schultz, J. L., \& Goff, E. (2010). The pedagogy of inclusion: Integrated multicultural instructional design. Journal of College Reading and Learning, 41(1), 49-66.

11. Higbee, J. L., \& Siaka, K. (2005). Students' assessment of their multicultural experiences in the General College: A pilot study. In J. L. Higbee, D. B. Lundell, \& D. R. Arendale (Eds.), The General College vision: Integrating intellectual growth, multicultural perspectives, and student development. Minneapolis, MN: University of Minnesota, General College, Center for Research on Developmental Education and Urban Literacy. Retrieved from http://cehd.umn.edu/CRDEUL/books-thegcvision.html

12. Higbee, J. L., Siaka, K., \& Bruch, P. L. (2007a). Assessing our commitment to multiculturalism: Student perspectives. Journal of College Reading and Learning, 37(2), 7-25.

13. Higbee, J. L., Siaka, K., \& Bruch, P. L. (2007b). Student perceptions of their multicultural learning environment: A closer look. In J. L. Higbee, D. B. Lundell, \& I. M. Duranczyk (Eds.), Diversity and the postsecondary experience (pp. 3-23). Minneapolis, MN: University of Minnesota, Center for Research on Developmental Education and Urban Literacy. Retrieved from http://cehd.umn.edu/CRDEUL/docs/monograph/Diversity.pdf

14. Jackson, S. E., Joshi, A., \& Erhardt, N. L. (2003). Recent research on team and organizational diversity: SWOT analysis and implications. Journal of Management, 29, 801-830.

15. Johnston, W. B. (1991). Global workforce 2000: The new world labor market. Harvard Business Review, 69(2), 115-127.

16. Kuczynski, S. (1999, December). If diversity then higher profits? HR Magazine, 66-74.

17. Loden, M. (1996). Implementing diversity. Boston, MA: Irwin.

18. Maslow, A. (1968). Toward a psychology of being. New York, NY: Van Nostrand.

19. Miksch, K. L., Higbee, J. L., Jehangir, R. R., Lundell, D. B., Bruch, P. L., Siaka, K., \& Dotson, M. V. (2003). Multicultural Awareness Project for Institutional Transformation: MAP IT. Minneapolis, MN:

University of Minnesota, General College, Multicultural Concerns Committee and Center for Research on Developmental Education and Urban Literacy. Retrieved from http://www.cehd.umn.edu/CRDEUL/pdf/map it.pdf

20. Sanford, N. (1967). Where colleges fail: A study of student as person. San Francisco, CA: Jossey-Bass.

21. Wilson, D. C. (2006, April 13). When equal opportunity knocks: A Gallup survey reveals what workplace diversity really means to employees, managers, and the balance sheet. The Gallup Management Journal. 


\section{APPENDIX}

\section{Course Evaluation Form \\ Promoting Inclusion and Retention through \\ Integrated Multicultural Instructional Design (PIRIMID) \\ HRD 5627: Management and Supervisory Development}

This course was designed using the principles of Integrated Multicultural Instructional Design (IMID), a model for developing inclusive curricula. On a 1 to 10 scale, where $1=$ "not at all" and $10=$ "outstanding," please evaluate the extent to which this course accomplished each of the following goals:

\section{Teaching Methods}

Instructor uses a variety of teaching methods (e.g., reading assignments, class discussions, film, small and large group activities, and student centered projects) that reflect a commitment to engaging a diverse student population.

$\begin{array}{llllllllll}\begin{array}{llllll}\text { Not at all } \\ 1\end{array} & 2 & 3 & 4 & 5 & 6 & 7 & 8 & 9 & \text { Outstanding } \\ \text { Comments }\end{array}$

\section{Course Content}

Instructor integrates multicultural perspectives (e.g., exploration of current events and issues related to race, ethnicity, religion, gender, sexual orientation, and disability) within the course content.
Not at all

$1 \quad 2 \quad 3 \quad 4$

56
7
8
9
Outstanding

Comments regarding course content:

\section{Evaluation of Student Learning}

Instructor uses assessment and grading procedures that provide equitable opportunities for success for all students in the course, including multiple ways for students to demonstrate knowledge (e.g., papers, peer presentations, accessible on-line exams, student-driven projects) and grading rubrics for papers and presentations.

$\begin{array}{lllllllllll}\begin{array}{llllll}\text { Not at all } \\ 1\end{array} & 2 & 3 & 4 & 5 & 6 & 7 & 8 & 9 & 10 \\ \text { Comments regarding evaluation of learning: } & & & & \end{array}$

\section{Commitment to Diversity and Multiculturalism}

Instructor articulates a commitment to diversity and multiculturalism and demonstrates that commitment through her/his teaching methods, course content, and procedures for evaluating student learning.

Not at all Outstanding
1
2
3
45
6
7
8
9
10
Comments related to faculty member's commitment to diversity and multiculturalism: 
NOTES 